\title{
Model of Multi Product Classification with Regular Demand on Inventory System in a Raw Material Supply Company
}

\author{
Tri Febrion Widiadvito ${ }^{1 *}$, Joniarto Parung ${ }^{2}$ \\ ${ }^{1}$ Fakultas Bisnis dan Ekonomika, Universitas Surabaya, Indonesia \\ ${ }^{2}$ Fakultas Teknologi Industri, Universitas Surabaya, Indonesia \\ E-mail: widiadvito@gmail.com, joniartoparung@yahoo.co.uk \\ * Corresponding Author
}

\section{ARTICLE INFO}

Article history

Received 2020-09-05

Revised 2020-09-19

Accepted 2020-09-26

Keywords

inventory management, $A B C$ analysis, multi product

\section{ABSTRACT}

The right strategy in inventory is the main point in maintaining adequate and guaranteed supply continuity. Inventory strategies are becoming important but complex when the number of items that must be prepared is increasing. In this regard, it is necessary to analyze the product groupings in several classifications. Prioritized products receive special attention.

The same problem is faced by PT PEKA, an import raw material distribution company that has nearly 2000 product items. Based on data demand is known, that the company's demand does not have a fixed pattern. Many products have regular and irregular demand, even the number of regular demand is very volatile. Companies often experience excess stock or vice versa due to lack of stock demand according to predictions, long lead times and product self-life that varies. Related to this, alternative product groupings or classifications are needed in accordance with company conditions. The company currently has frozen and unfrozen products, has items made from natural and non-natural raw materials and has a short and relatively long lead time.

PT. PEKA groups products in various stages, which lead to a combination of $A B C$ and $X Y Z$ classifications. Demand of priority items generated from the grouping is then forecast according to the model that gives the smallest MSE / MAD. Furthermore, a case study was carried out to calculate the Total Relevance Cost (TRC) from the calculation results to be compared with the real TRC. TRC according to the classification results was $R p$. 1,293,370,148, - lower than the actual condition TRC, which amounted to Rp. 1,805,887,874,

\section{INTRODUCTION}

The right strategy in inventory is the main point in maintaining adequate and guaranteed supply continuity. Inventory strategies are becoming increasingly important but complex when the number of raw material items to be prepared is relatively large. The approach based on product grouping analysis is expected to divide the raw material products into several classifications. Priority products can be mapped so that they can be a concern and a basis in making decisions for procurement and marketing strategies. (Gasperez, 1998)

Many case studies have been carried out in classifying products for various purposes, almost all of which aim to find effective and efficient methods that can reduce costs. Several studies that have been carried out only provide an alternative solution model by developing existing $A B C$ theory, not focusing on the ABC-XYZ classification method and without considering the type of product being managed. There are also case studies of irregular and multi-item product conditions with uniform storage handling characteristics.(Jay et al, 2014)

Nenes, Panagiotidou, and Tagaras (2010) conducted research on inventory management for multiple items with irregular demand by taking cases from wheel and caster distributor companies. With thousands of product items supplied from 20 countries in Europe and Asia, they are sold to many different types of customers. By using accurate demand modeling with gamma distribution 
or poisson distribution models for slow moving items, and developing efficient procedures to obtain accurate stock levels.

Mohammaditabar, Ghodsypour and O'Brien (2010) suggest a model that simultaneously combines inventory item classifications and policies that are appropriate for each group with the aim of obtaining effective inventory performance. The resulting model was compared with the findings of other methods and the differences and total available values were sought.

Jin-Xiao Chen (2011) writes about multi criteria ABC Inventory Control (MCIC), using a weighting and aggregating approach to the most favorable and most unfavorable factors for each product item objectively then compared with the previous method which is illustrated. based on MCIC problem.

Jiapeng Liu, Xiuwu Liao, Wenhong Zhao and Na Yang (2015) suggest an alternative approach based on the outranking relationship defined in ELECTRE for the MCABC problem when non-compensation between criteria must be considered. This approach differentiates from the previous MC ABC method by adding new features. The first is to consider non compensation between the criteria on the $\mathrm{MC} \mathrm{ABC}$ problem. The two clustering analyzes were combined into the $\mathrm{ABC}$ classification process. The third is to simulate annealing algorithm to find optimal solutions based on the resulting cluster hierarchy. (Ma, 2012)

The difference between this research and what has been done is that it focuses more on the use of the $\mathrm{ABC}-\mathrm{XYZ}$ theory with the grouping stages between the $\mathrm{ABC}$ and $\mathrm{ABC}-\mathrm{XYZ}$ classifications, where after the $\mathrm{ABC}$ classification is carried out, the A classification will be grouped according to storage method, product origin and time span. order before making the $\mathrm{ABC}$ $\mathrm{XYZ}$ matrix. Another difference is the characteristics of the product being managed, where this research is a case study with real data on perishable goods products and has different storage and supply handling categories in national companies supplying raw materials for drugs, food and beverages.(Ivanov, 2019)

As a case study is a company that supplies raw materials for the food and pharmaceutical industries. PT PEKA, which has been a supplier of imported raw materials for the food and pharmaceutical industries since 1958, is headquartered in Jakarta and is assisted by 10 branch offices located in the major cities of Java and Bali, as well as Makassar and Palembang.

PT PEKA's problems are getting more complicated when observing demand data that does not have a fixed pattern. There are many products whose demand is regular but the amount fluctuates, large in the previous year, but decreased in the following year. On the other hand, there are products whose demand in the previous 2 years was relatively low but in the following years it was high. There are also products whose demand was there in the previous year but became zero in the following year and even 2 years later. There are still many erratic demand patterns at PT PEKA, which also have a risk of self-life problems (expiration). Therefore, accurate and precise product classification is a need that needs to be prepared so that more attention is paid to products with important classifications. (Dwiantara et al, 2004)

It is hoped that more precise grouping of inventory products can make it easier for the inventory section to determine the buffer stock and re-order points of each product based on forecast, self-life and lead time orders (Makridakis, 1999).

\section{METHOD}

This research is applied research because it is conducted to provide alternative solutions to problems experienced by a company (PT PEKA). In practice, the paradigm used is the positivism paradigm. In the positivism paradigm, the ontology assumption is used that reality is external and objective using quantitative measures. Meanwhile, epistemologically, this study assumes that this research is meaningful because it is carried out through direct observation in the field according to the real conditions in the field (Parung, 2012). 
Seeing the supply chain constraints and problems at PT PEKA, such as the number of product items being managed, different types of storage, long lead time for orders, product availability at suppliers and unstable prices, resulting in low forecast accuracy, it is necessary to create a system which can help facilitate the supply chain team in carrying out inventory management through product grouping.

The grouping of products that will be carried out this time is to separate regular and irregular products first. Then regular products will be grouped again using the ABC classification formula, while irregular products are not included in the classification, but must be analyzed separately. In this paper, we only discuss regular products that will be grouped using the ABC classification, because in the grouping that has been done, the contribution of regular product sales reaches more than $90 \%$. (Mulyadi, 2007)

After obtaining the $\mathrm{ABC}$ grouping of regular products, product group A will be used as an example to be regrouped based on the storage method. Where there are 4 ways of storage that are differentiated by temperature, namely:

1. Frozen, for storage with freezing temperatures below $-150 \mathrm{C}$

2. Chilled, for storage at a temperature between $0 \mathrm{o}-5 \mathrm{o} \mathrm{C}$

3. Control, for storage with temperatures between $150-25$ o C

4. Dry, for storage at room temperature

Apart from different types of storage, factors that influence this storage process are long lead time variations and product availability which depends on the season because they are natural products. So after classifying the storage method, the results of the grouping will again be divided into two classifications, namely natural or non-natural products to separate which ones are available depending on the weather or season and those which are not seasonal.

To be more precise, products will be regrouped to separate products based on their lead time. It is hoped that this detailed classification modeling will make it easier to monitor key products in their application in the field.

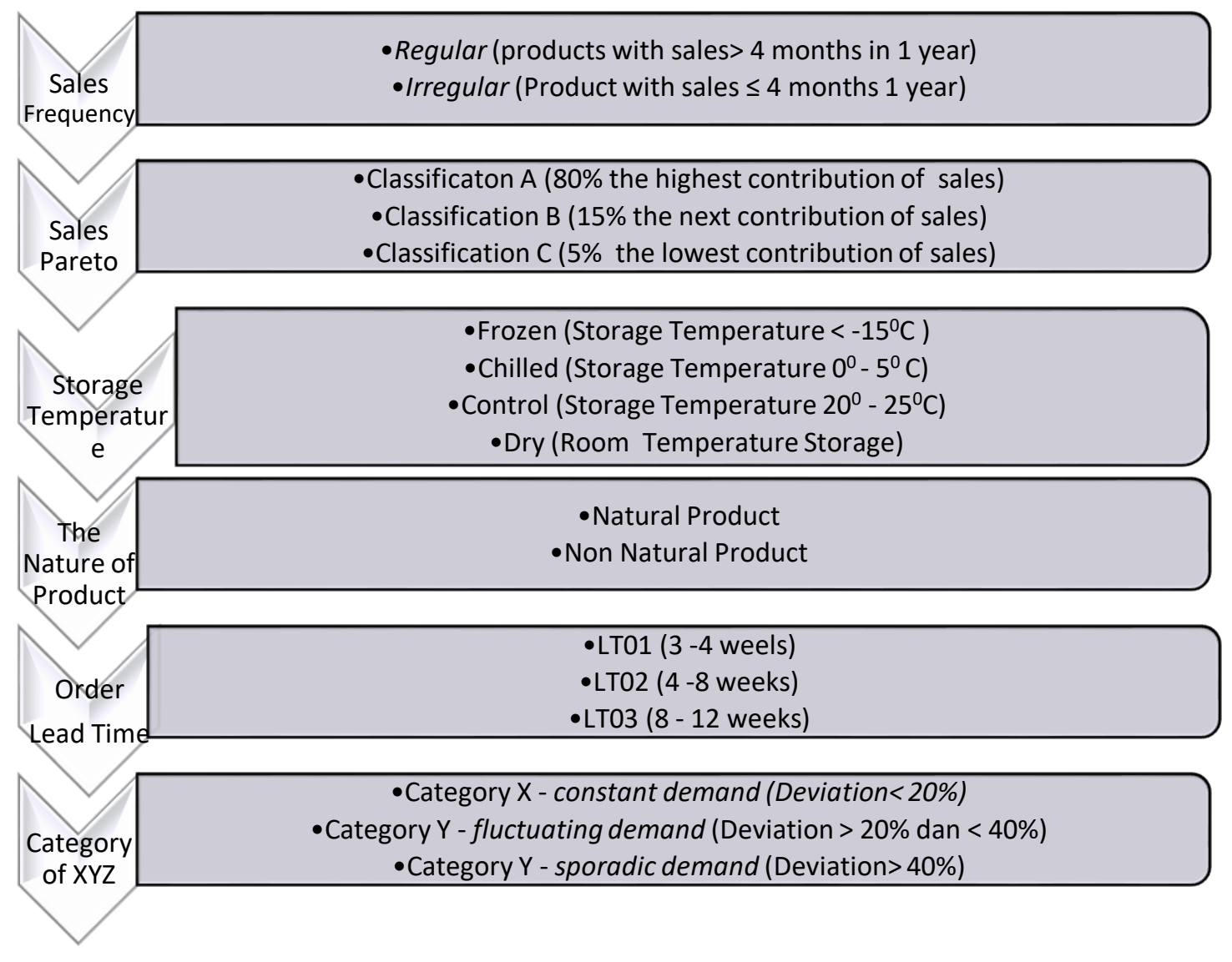


Fig. 1. Steps to Classify Products

\section{RESULT AND DISCUSSION}

From the sales data for 2018, regular and irregular products are separated, then products that are included in the regular category are grouped back into the $\mathrm{ABC}$ classification. Products in classification A, which represent $20 \%$ contribution to the sales value of regular products, are reclassified according to storage method, nature of product origin and product order lead time. After the grouping is done, there are 20 products that will be analyzed to make a forecast to calculate the demand for the next 10 months.

Forecasts are made using historical sales volume data for 3 years (2016, 2017 and 2018) calculated by the Minitab program. From the Minitab program data, the researcher analyzed each product based on the smallest MAP, MSD or MAPE values to be taken as the basis for determining demand for the next 10 months. Before testing the calculations, the researcher reanalyzed all the resulting forecast values by looking at the sales patterns and sales trends that had occurred in the last 3 years. Forecast results for the next 10 months can be seen in table 3.1 below.

Tabel 1. Demand hasil perhitungan program Minitab

\begin{tabular}{|c|c|c|c|}
\hline \begin{tabular}{c|l} 
Product & de \\
Code & duk
\end{tabular} & Model del & $\begin{array}{l}\text { Total Demand } \\
\text { in } 10 \text { months }\end{array}$ & nd 10 \\
\hline $\mathrm{P} 000242$ & Moving Average & 9,510 & \\
\hline P000590 & Moving Average & 5,576 & \\
\hline P000591 & Moving Average (6 Mo) & 2,910 & \\
\hline P000592 & Moving Average (6 Mo) & 3,940 & \\
\hline $\mathrm{P} 000593$ & Growth Curve & 6,745 & \\
\hline P000656 & Moving Average & 9,720 & \\
\hline P000657 & S-Curve Trend & 1,670 & \\
\hline P000658 & Moving Average (low) & 97,600 & \\
\hline P000660 & Moving Average (upper) & 30,120 & \\
\hline P000816 & Moving Average & 9,080 & \\
\hline P000929 & Moving Average (6 Mo) & 5,410 & \\
\hline P001047 & Moving Average & 1,100 & \\
\hline P001410 & Moving Average (upper) & 4,500 & \\
\hline P001419 & Growth Curve & 10,166 & \\
\hline P001424 & Moving Average & 5,030 & \\
\hline P001641 & Moving Average & 7,770 & \\
\hline
\end{tabular}

Before calculating the Total Relevancy Cost, the researcher adjusts the total demand for the next 10 months with the Minimum Order Quantity (MOQ) of each product (as in Table 2), so that the calculation results can later be applied according to real conditions in the field. 
Table 2. Demand Modification According to the MOQ

\begin{tabular}{|c|c|c|c|}
\hline \multicolumn{2}{|c|}{ Product fluk } & MOQ & \multicolumn{2}{|c|}{$\mathbf{D}(\mathbf{F}$ D Modification } \\
\hline & & \multicolumn{2}{|c|}{ ikasi } \\
\hline P000242 & 1,160 & 9,510 & 9280 \\
\hline P000590 & 1,000 & 5,576 & 5000 \\
\hline P000591 & 750 & 2,910 & 3000 \\
\hline P000592 & 1,000 & 3,940 & 4000 \\
\hline P000593 & 900 & 6,745 & 6300 \\
\hline P000656 & 2,630 & 9,720 & 7890 \\
\hline P000657 & 1,315 & 1,670 & 1315 \\
\hline P000658 & 2,630 & 97,600 & 97310 \\
\hline P000660 & 1,600 & 30,120 & 30400 \\
\hline P000816 & 1,315 & 9,080 & 9205 \\
\hline P000929 & 800 & 5,410 & 5600 \\
\hline P001047 & 600 & 1,100 & 1200 \\
\hline P001410 & 2,000 & 4,500 & 6000 \\
\hline P001419 & 788 & 10,166 & 10244 \\
\hline P001424 & 2,500 & 5,000 & 5000 \\
\hline P001641 & 3,030 & 9,090 & 9090 \\
\hline
\end{tabular}

After obtaining the modified forecast figures for the next 10 months, the demand forecast in 10 months is used to calculate the Total Relevancy Cost (Trc) of the inventory for each product using the following formula:

$$
\begin{gathered}
\operatorname{Trc}=\text { Inventory cost }+ \text { Order cost } \\
\operatorname{Trc}=\left(\frac{Q}{2} \times P \times f\right)+\left(\frac{D}{Q} \times C\right)
\end{gathered}
$$

where

Trc = Total Relevancy Cost

$\mathrm{Q}=$ Product Quantity of Each Order

$\mathrm{P} \quad=$ Product Price

$\mathrm{f} \quad=$ Storage Cost Fraction

$\mathrm{D} \quad=$ Annual Demand

$\mathrm{C} \quad=$ Order Cost

The number of products in each order can be calculated using the economic order quantity (EOQ) formula as follows:

$$
Q=\sqrt{\frac{2 C D}{H}}
$$

where $\mathrm{H} \quad=$ Storage Cost $(\mathrm{f} \times \mathrm{P})$

In the calculation of this modification, the value of $\mathrm{Q}$ (number of products in each order) uses the minimum order quantity (MOQ) of each product. The results of the calculations can be seen in Table 3 
Table 3. The Calculation Results of Total Relevancy Cost (TRC)

\begin{tabular}{|r|c|c|r|r|r|r|r|r|r|}
\hline Produk & P & f & \multicolumn{1}{c|}{ C } & D (modif) & $\mathbf{H}=(\mathbf{P}$ f $)$ & \multicolumn{1}{c|}{$\mathbf{Q}$} & \multicolumn{1}{c|}{ Tic } & \multicolumn{1}{c|}{ Toc } & \multicolumn{1}{c|}{ Trc } \\
\hline P000242 & 207,800 & 0.0210 & $6,000,000$ & 9,280 & 5,237 & 1,160 & $2,531,004$ & $48,000,000$ & $50,531,004$ \\
\hline P000590 & 486,280 & 0.0210 & $8,500,000$ & 5,000 & 12,254 & 1,000 & $5,105,940$ & $42,500,000$ & $47,605,940$ \\
\hline P000591 & 562,526 & 0.0210 & $8,500,000$ & 3,000 & 14,176 & 750 & $4,429,892$ & $34,000,000$ & $38,429,892$ \\
\hline P000592 & 565,312 & 0.0210 & $8,500,000$ & 4,000 & 14,246 & 1,000 & $5,935,776$ & $34,000,000$ & $39,935,776$ \\
\hline P000593 & 656,862 & 0.0210 & $8,500,000$ & 6,300 & 16,553 & 900 & $6,207,346$ & $59,500,000$ & $65,707,346$ \\
\hline P000656 & 394,240 & 0.0210 & $13,480,000$ & 7,890 & 9,935 & 2,630 & $10,886,938$ & $40,440,000$ & $51,326,938$ \\
\hline P000657 & 353,165 & 0.0210 & $8,500,000$ & 1,315 & 8,900 & 1,315 & $4,876,326$ & $8,500,000$ & $13,376,326$ \\
\hline P000658 & 349,191 & 0.0210 & $13,480,000$ & 97,310 & 8,800 & 2,630 & $9,642,909$ & $498,760,000$ & $508,402,909$ \\
\hline P000660 & 159,800 & 0.0210 & $6,000,000$ & 30,400 & 4,027 & 1,600 & $2,684,640$ & $114,000,000$ & $116,684,640$ \\
\hline P000816 & 308,193 & 0.0210 & $13,480,000$ & 9,205 & 7,766 & 2,630 & $8,510,750$ & $47,180,000$ & $55,690,750$ \\
\hline P000929 & 337,447 & 0.0210 & $7,500,000$ & 5,600 & 8,504 & 800 & $2,834,555$ & $52,500,000$ & $55,334,555$ \\
\hline P001047 & 843,000 & 0.0210 & $6,900,000$ & 1,200 & 21,244 & 600 & $5,310,900$ & $13,800,000$ & $19,110,900$ \\
\hline P001410 & 915,097 & 0.0210 & $6,900,000$ & 6,000 & 23,060 & 2,000 & $19,217,037$ & $20,700,000$ & $39,917,037$ \\
\hline P001419 & 132,958 & 0.0210 & $8,840,000$ & 10,244 & 3,351 & 788 & $1,100,094$ & $114,920,000$ & $116,020,094$ \\
\hline P001424 & 633,570 & 0.0210 & $6,900,000$ & 5,000 & 15,966 & 2,500 & $16,631,213$ & $13,800,000$ & $30,431,213$ \\
\hline P001641 & 759,542 & 0.0210 & $6,900,000$ & 9,090 & 19,140 & 3,030 & $24,164,829$ & $20,700,000$ & $44,864,829$ \\
\hline
\end{tabular}

Where TIC is Total Inventory Cost and TOC is Total Order Cost. Henceforth, the results of the calculation of the Total Relevancy Cost (Trc) above will be compared with the actual conditions that have occurred. The actual data used is the data on the number of goods entered in each product item in the 37th month to the 46th month and the data on the average number of goods that each time entered into each product.

As a comparison, the results of the calculation of existing demand and total relevancy cost (TRC) will be compared with the actual data on goods receipts for the next 10 months and also the actual total relevancy cost (actual Trc). The results of this comparison can be seen in Table 4

Data $\mathrm{D}$ in Table 4 is the modified demand forecast and data $\mathrm{D}$ (actual) is the actual data on the procurement of each product in the next 10 months.

Table 4. Comparison of TRC and Actual Demand with The Results of Forecast Calculations

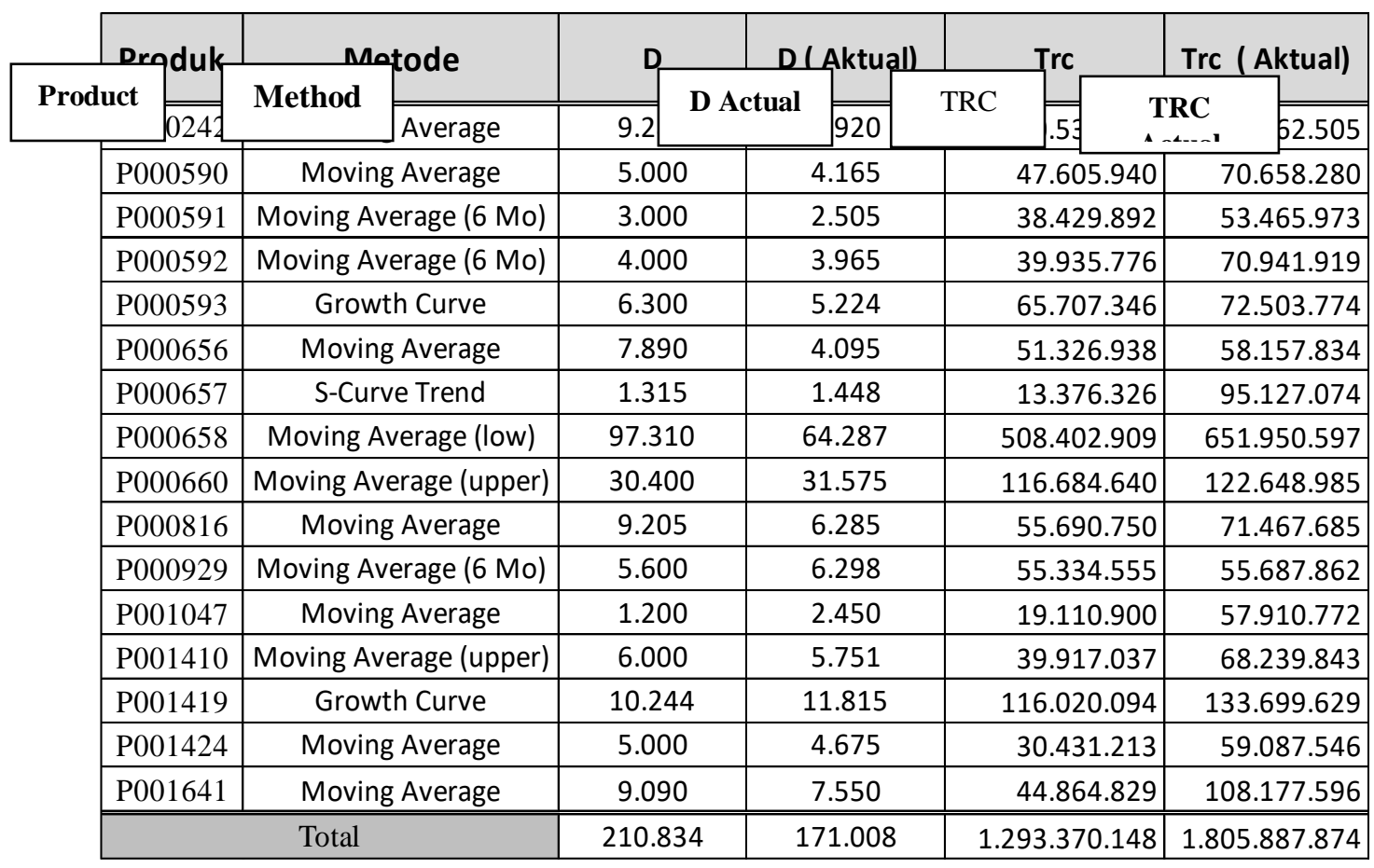


The Total Value of Relevancy Cost (TRC) in the results of the calculation of this study is (Rp. $1,293,370,148,00$ ), indicating a smaller number when compared to the value of Total Relevancy Cost (TRC) with actual goods procurement data (Rp. 1,805,887,874,00) and this smaller value also occurs in all product items that have been researched, but not all the calculated demand values are smaller than the actual procurement value that has been carried out. For example, it can be seen in products that have the biggest difference in demand value calculated and actual procurement, namely product P000656, where the demand value calculated from forecast after modification following the MOQ is 7,890 cartons and the actual number of goods procured is 4,095 cartons, but the value of TRC From the calculation forecast of Rp. 51,326,938,00 is still smaller than the TRC value of the actual procurement of Rp. 58,157,834,00. This can occur because of the difference in the minimum quantity $(\mathrm{Q})$ in ordering goods, where the actual order data does not follow the applicable MOQ. Several reasons can be explained because of the existence of management policies in reducing DOI (days of inventory) of a product.

There are several reasons for management to take a policy to reduce goods orders, one of which is because there are still many carry-over stock from the previous period, this can be seen in the actual sales data for P000656 products in Table 3 which shows sales figures of 7,913 cartons. Logically it can be concluded, how could there be a sale of 7,913 cartons by only procuring 4095 cartons of goods.

Table 5. Current Year Actual Sales Data, Goods Orders Actual and Demand Research Results from Forecast Calculations

\begin{tabular}{|c|c|c|c|c|}
\hline Product & $\begin{array}{c}\text { Actual } \\
\text { Sales }\end{array}$ & $\begin{array}{c}\text { D Actual } \\
\text { Order }\end{array}$ & $\begin{array}{l}\text { anan } \\
\text { al) }\end{array}$ & D (Fc) \\
\hline \hline & P000242 & 6.919 & 8.920 & 9.280 \\
\hline & P000590 & 3.899 & 4.165 & 5.000 \\
\hline P000591 & 3.001 & 2.505 & 3.000 \\
\hline & P000592 & 3.674 & 3.965 & 4.000 \\
\hline & P000593 & 5.496 & 5.224 & 6.300 \\
\hline & P000656 & 7.913 & 4.095 & 7.890 \\
\hline P000657 & 1.586 & 1.448 & 1.315 \\
\hline P000658 & 87.305 & 64.287 & 97.310 \\
\hline P000660 & 28.639 & 31.575 & 30.400 \\
\hline P000816 & 8.458 & 6.285 & 9.205 \\
\hline P000929 & 5.643 & 6.298 & 5.600 \\
\hline P001047 & 1.860 & 2.450 & 1.200 \\
\hline P001410 & 5.112 & 5.751 & 6.000 \\
\hline P001419 & 10.656 & 11.815 & 10.244 \\
\hline P001424 & 4.438 & 4.675 & 5.000 \\
\hline P001641 & 7.494 & 7.550 & 9.090 \\
\hline
\end{tabular}

One more finding from the researcher, the reason for management in reducing the number of goods orders so that they do not follow the MOQ is because the current storage capacity is very limited, even though the company has made additional investments, but it has not been able to keep up with the rate of business growth that has occurred. So that a step is taken to bring in the product gradually. This is done to maintain the company's cash flow as well.

\section{CONCLUSION}

PT PEKA has used a product classification system, but in its application in the field it is not maximally applied, because in determining re-order points or decisions to procure products, it does not use the basis for grouping that has been made and does not follow the optimal MOQ. In practice, the company's supply chain team relies more on or waits for procurement requests from the sales team, so that the forecasts that have been made do not function optimally. In this study, it 
is known that the product grouping with regular demand that can be applied effectively is the ABC and XYZ models

The classification model and inventory system policy at PT PEKA is carried out in 5 stages, starting from $\mathrm{ABC}$ classification which is then reclassified into frozen-non-frozen, natural-nonnatural products and based on lead time. Furthermore, the results of the grouping are reclassified into the XYZ model to determine products with constant and fluctuating demand. The results of the forecast and product grouping that have been carried out in this research have resulted in a Trc (Toatal Relevancy Cost) figure of IDR 1,293,370,148, which is lower than the actual conditions that have occurred (IDR 1,805,887,874, -). This shows if there is still room for efficiency, which in the end can save company expenses so that it can provide greater profits.

The main obstacle in implementing the inventory system that has been created is the lead time and the MOQ (minimum order quantity) of each product. Calculations carried out in this paper, the MOQ is determined based on data 1 FCL (full container load) of each product. So that the forecast value that has been obtained from the calculation results of the Minitab program, is modified the forecast amount to adjust the MOQ.

Meanwhile, in real conditions, orders are still influenced by several other factors, such as product availability in the market and lead time as well as management policies in making decisions on quantities in procurement of goods with consideration of DOI (days of inventory), cash flow and warehouse capacity.

To get a more optimal and accurate forecast, it is highly recommended that the results of forecast calculations from this product grouping be discussed first with the sales team and company management regarding sales strategies and plans, so that it will maximize forecast accuracy.

After the forecast is obtained from the calculation results and talks with the sales team and company management, the supply chain team must take into account the plan to bring the product in relation to the MOQ, so that a more accurate decision will be made in making a procurement plan. It is possible to combine shipments in the plan to bring in products.

Because product items have a lot of regular demand (approximately 750 product items), PT PEKA should separate the inventory management process for regular products, so that the supply chain team can concentrate more on regular products and contribute more to sales at PT. PEKA. Meanwhile, products with an irregular category can be reclassified based on their sales contribution and re-procurement according to needs (just in time). In certain cases, it is highly recommended to remove these products from PT PEKA's product list so that the supply chain team can work more effectively and efficiently.

In addition, the elimination of irregular products will also have an impact on the efficiency of storage capacity, so that the space that has been used to store irregular products can be used as storage space for regular products which contributes more to sales value.

\section{REFERENCES}

Chen JX. 2011, Peer-estimation formultiple criteria ABC inventory classification. Computers \& Operations Research 2011;38(12):1784-91.

Dwiantara,L dan Sumarto, RH.2004. Manajemen Logistik. Jakarta:Grasindo.

Gasperez, Vincent. 1998. Production Planning and Inventory Control. Jakarta: Gramedia Pustaka Utama 
George Nenes, Sofia Panagiotidou, George Tagaras, 2010, Inventory management of multiple items with irregular demand : A case study, European Journal of Operational Research 205 (2010):313-324

Ivanov Dmitry, Tsipoulanidis A, Schonberger J, 2019. Global Supply Chain and Operations Management, second edition. Springer

Jay, Heizer dan Barry, render. 2014, Operation Management, sustainability and supply chain management, eleventh edition. Pearson

Jiapeng Liu, Xiuwu Liao, wenhong Zhao, Na Yang. 2015, A classification approach based on the outranking model for multiple criteria ABC analysis, Omega 63(2016):19-34

Ma LC. 2012, A two-phase case-based distance approach for multiple-group classi- fication problems. Computers and Industrial Engineering2012;63(1):89-97.

Makridakis. 1999. Metode dan aplikasi peramalan. Edisi 2. Jakarta: Binarupa Aksara

Mohammaditabar D, Ghodsypour SH, O'Brien C.2011, Inventory control system design by integrating inventory classification and policy selection

Mulyadi, 2007. Sistem Perencanaan dan Pengendalian Manajemen. Salemba Empat. Jakarta.

Parung, J., 2012, Merancang penelitian berbasis outcome, paradigma dan strategi,Brilian Internasional Surabaya, 2012 